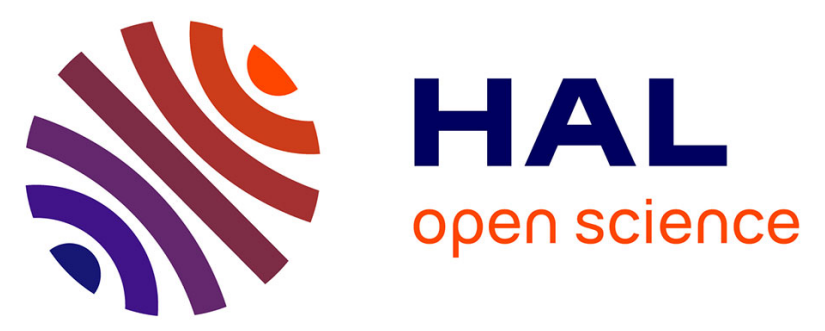

\title{
Isomerization-hydroboration-oxidation strategy: Access to long chain AB- and AA-type oleyl based monomers and polymers thereof
}

Prakash Sudhir Sane, Thomas Lebarbé, Etienne Grau, Henri Cramail

\section{- To cite this version:}

Prakash Sudhir Sane, Thomas Lebarbé, Etienne Grau, Henri Cramail. Isomerization-hydroborationoxidation strategy: Access to long chain AB- and AA-type oleyl based monomers and polymers thereof. European Journal of Lipid Science and Technology, 2016, 118 (11), pp.1620-1629. 10.1002/ejlt.201600064 . hal-01411518

\author{
HAL Id: hal-01411518 \\ https://hal.science/hal-01411518
}

Submitted on 26 Nov 2019

HAL is a multi-disciplinary open access archive for the deposit and dissemination of scientific research documents, whether they are published or not. The documents may come from teaching and research institutions in France or abroad, or from public or private research centers.
L'archive ouverte pluridisciplinaire HAL, est destinée au dépôt et à la diffusion de documents scientifiques de niveau recherche, publiés ou non, émanant des établissements d'enseignement et de recherche français ou étrangers, des laboratoires publics ou privés. 


\title{
Isomerization-Hydroboration-Oxidation Strategy: Access to Long Chain AB- and
}

\section{AA-type Oleyl Based Monomers and Polymers Thereof}

\author{
Prakash Sane ${ }^{a, b}$ Thomas Lebarbéc, Etienne Grau, ${ }^{a, b}$ and Henri Cramail a,b *
}

a Centre National de la Recherche Scientifique, Laboratoire de Chimie des Polymères Organiques, UMR 5629, ENSCBP, 16 avenue Pey-Berland, F-33607 Pessac Cedex, France, E-mail: cramail@enscbp.fr

${ }^{b}$ Univ. of Bordeaux, Laboratoire de Chimie des Polymères Organiques, UMR 5629, Bordeaux INP/ENSCBP, 16 avenue Pey-Berland, F-33607 Pessac Cedex, France

c ITERG, 11 rue Gaspard Monge, F-33600 Pessac Cedex, France

\section{Abstract}

A strategy to convert by Isomerization-Hydroboration-Oxidation reaction the internal double bond of oleic acid to a terminal alcohol function, leading to linear long-chain $\alpha, \omega$-difunctional substrates has been investigated. Using this strategy, oleic acid-based AB- and AA-monomers were prepared and characterized by FTIR-ATR and NMR spectroscopy. Thermoplastic aliphatic linear polyesters, polycarbonates and polyurethanes were then synthesized by reacting the soformed bio-based monomers via polycondensation in bulk, using 1,5,7-triazabicyclo[4.4.0]dec-5ene (TBD) as an organocatalyst. Thus, starting from easily available bio-based starting compound, the synthesis of linear long methylene chain aliphatic polyesters, polycarbonates and polyurethanes (by isocyanate free route) is reported. The structural and thermal characterizations of the synthesized polymers were performed by means of NMR, SEC, DSC and TGA experiments. 


\section{Introduction}

The synthesis of bio-based chemicals and materials from renewable resources represents today an important topic that captured the attention of researchers from academy and industry [1-3]. Fatty acids are a unique feedstock for the production of chemicals because of their characteristic long methylene chain sequences [4-6]. These fatty acids are already endowed with a functional group in the form of the carboxylic group. For many applications, a further functionality is required. The double bonds of unsaturated fatty acids enable their postmodification and the generation of additional functional groups. Such mono or multiple unsaturated fatty acids are contained in substantial amounts in common plant oils. Alkali fusion [7], thermal rearrangement [8], ozonolysis $[9,10]$ processes towards the synthesis of $\alpha, \omega$-difunctional compounds are reported but in all of these processes, only a part (roughly half) of the fatty acid chain is incorporated into the resulting $\alpha, \omega$-difunctional product. Thus, the full potential of the long methylene sequences of the fatty acid to impart useful properties such as hydrophobicity or cristallinity is not valorized. Incorporation of the entire length of the fatty acid chain into $\alpha, \omega$-functionalized compounds is thus a challenging task. This requires the conversion of the internal double bond of the fatty acid chain into a terminal functional group [10]. Therefore, an isomerization step is necessary, followed by an efficient and selective functionalization of the unsaturation in terminal position. Such a terminal functionalization of long-chain compounds, for instance methyl oleate, is particularly difficult because the isomerization reaction leads to a mixture of isomers at the thermodynamic equilibrium that contains very few amounts of the terminal olefin [11]. In the past few years, fatty acids containing internal double bonds were derivatized into different substrates following various 
approaches such as isomerization-alkoxycarbonylation [12-14], isomerization-hydroformylation $[15,16]$, isomerization-hydro-aminomethylation [17] and isomerization-hydrozirconation [18]. Isomerization-hydroboration-oxidation is another strategy used to synthesize $\omega$-alcohol functionalized monomers. Interestingly, Schäfer et. al. [19] demonstrated that hydroborationthermal isomerization followed by oxidation of boronated adduct could lead to different diols starting from oleyl alcohol. However, high temperature around $220{ }^{\circ} \mathrm{C}$ is required for the thermal isomerization of boronated adducts. Angelici et. al. [20] reported that Ir catalyst could induce the isomerization-hydroboration leading selectively to the $\omega$-boronated methyl oleate at temperature as low as room temperature.

In the last years, our research group has been focusing on the synthesis of new aliphatic polyesters and polyurethanes from vegetable oils [21-24]. Herein, we report, a process in mild condition of isomerization-hydroboration-oxidation of different oleic acid derivatives to prepare A-B and A-A type condensable monomers and investigate their polymerization to prepare novel polyesters, polycarbonates and polyurethanes.

\section{Experimental}

\subsection{Materials and instrumentation}

1,5,7- Triazabicyclo[4.4.0]dec-5-ene (TBD, 98\%), dimethyl carbonate (DMC), hydrogen peroxide $\left(30 \% \mathrm{H}_{2} \mathrm{O}_{2}\right)$, chlorobis (cyclo-octene) iridium (I) dimer $\left[\operatorname{Ir}(\mathrm{COE})_{2} \mathrm{Cl}\right]_{2}$ were obtained from SigmaAldrich. Methyl oleate (99\%) and olely alcohol (99\%) were purchased from NU CHEK PREP INC, USA. Tetramethyl-1,3,2-dioxaborolane (pinacol borane) (97\%), ethylenebis(diphenyl phosphine) (DPPE) were purchased from Alfa Aesar. All products and solvents (reagent grade) were used as

received. ${ }^{1} \mathrm{H}-\mathrm{NMR}$ and ${ }^{13} \mathrm{C}-\mathrm{NMR}$ spectra were recorded using a Bruker $\mathrm{AC}-400 \mathrm{NMR}$ at room 
temperature by dissolving the samples in $\mathrm{CDCl}_{3}$. Infrared spectra were obtained on a BrukerTensor 27 spectrometer using the attenuated total reflection (ATR) mode. The spectra were acquired using 16 scans at a resolution of 4 wavenumbers. Size exclusion chromatography (SEC) analyses were performed at room temperature in THF with a setup consisting of a WATERS 880PU pump and a series of three micro-styragel columns with pore sizes of 103, 105 and $106 \AA$ using polystyrene (PS) standards. Thermogravimetric analyses (TGA) were recorded using a TGA Q50 apparatus from TA instruments. Polymer samples, using 5-10 mg were heated from $30{ }^{\circ} \mathrm{C}$ to $700{ }^{\circ} \mathrm{C}$ at a rate of $10{ }^{\circ} \mathrm{C} \mathrm{min}^{-1}$ under nitrogen atmosphere and temperatures leading to $5 \mathrm{wt}$ $\%$ loss and 50 wt \% loss degradation were measured. Differential scanning calorimetry (DSC) thermograms were obtained from a DSC Q100 apparatus from TA instruments. Polymer samples, 5-10 mg sealed in hermetic aluminum pan, were first heated from -100 to $200{ }^{\circ} \mathrm{C}$ and then, the glass transition temperatures and melting points were determined from a second heating run. All runs were performed at a rate of $10^{\circ} \mathrm{C} \mathrm{min}^{-1}$.

\subsection{Typical Monomer Synthesis: Example of AB-Type monomer (I) for aliphatic polyurethane}

\section{Synthesis of Oleyl carbamate}

The procedure for the synthesis of oleyl carbamate starting from oleyl amine was followed as reported for the synthesis of oleyl carbonate starting from oleyl alcohol earlier from our group [25].

In a typical procedure, a two-necked round bottom flask equipped with magnetic stirrer, was charged with oleyl amine (10 g, $37.38 \mathrm{mmol})$ and 1,5,7-triazabicyclo[4.4.0]dec-5-ene (TBD) (0.25 g, $1.869 \mathrm{mmol}, 5 \mathrm{~mol} \%$ based on oleyl amine) and the mixture stirred at $90{ }^{\circ} \mathrm{C}$ under nitrogen atmosphere. After 10 minutes, excess of dimethyl carbonate, DMC (30 mL), was added and the reaction mixture was carried out for $6 \mathrm{~h}$. The excess of DMC was removed by distillation and the 
reaction mixture was recovered into dichloromethane (DCM) $(100 \mathrm{~mL})$. The DCM solution was washed with water ( $3 \times 40 \mathrm{~mL})$, followed by brine solution ( $1 \times 40 \mathrm{~mL}$ ). The $\mathrm{DCM}$ solution was dried over anhydrous sodium sulfate and filtered through a pad of celite. The removal of solvent yielded oleyl carbamate, as pale yellow oil-11.60 g (Yield: 96\%).

IR $\left(\mathrm{cm}^{-1}\right): 3334(-\mathrm{NH}), 1710(-\mathrm{NHCOO})$.

${ }^{1} \mathrm{H}-\mathrm{NMR}\left(400 \mathrm{MHz}, \mathrm{CDCl}_{3}, \delta \mathrm{ppm}\right): 5.31$ (m, 2H, CH=CH). 4.80 (bs, $\left.1 \mathrm{H}, \mathrm{NH}-\mathrm{CO}-\mathrm{OCH}_{3}\right), 3.64(\mathrm{~s}, 3 \mathrm{H}$, $\left.\mathrm{OCH}_{3}\right), 3.13\left(\mathrm{~m}, 2 \mathrm{H}, \mathrm{J}_{\mathrm{HH}}=7.5 \mathrm{~Hz}, \mathrm{CH}_{2}-\mathrm{NHCO}\right), 2.02\left(\mathrm{~m}, 4 \mathrm{H}, \mathrm{CH}_{2}-\mathrm{CH}=\mathrm{CH}\right), 1.59$ (q, 2H, $\mathrm{CH}_{2}-$ $\left.\mathrm{CH}_{2} \mathrm{NHCOO}\right), 1.40-1.10\left(-\mathrm{CH}_{2}\right), 0.88\left(\mathrm{~s}, 3 \mathrm{H}, \mathrm{CH}_{3}\right)$.

\section{Isomerization-Hydroboration-Oxidation of oleyl carbamate}

\section{Isomerization-Hydroboration}

The procedure for the Isomerization-Hydroboration of oleyl carbamate was followed as reported by Angelici et. al. [20].

A two-necked round bottom flask equipped with a magnetic stirrer, was charged with $\left[\operatorname{Ir}(\mathrm{COE})_{2} \mathrm{Cl}\right]_{2}(0.055 \mathrm{~g}, 0.062 \mathrm{mmol})$ and 1,2-bis(diphenylphosphino)ethane (dppe) $(0.05 \mathrm{~g}, 0.124$ mmol) under an argon flow. Methylene chloride $(3 \mathrm{~mL})$ was added to give a clear orange solution, which was stirred for $5 \mathrm{~min}$. To this solution were added oleyl carbamate $(0.6 \mathrm{~g}, 1.86$ $\mathrm{mmol}$ ) and pinacolborane $(0.23 \mathrm{~mL}, 1.86 \mathrm{mmol})$, and the reaction mixture was stirred for $30 \mathrm{~h}$ at room temperature. The resulting light yellow solution was diluted with $100 \mathrm{~mL}$ of methylene chloride and filtered through silica gel to remove the catalyst. The filtrate was then evaporated under reduced pressure and the obtained mixture on flash chromatographic separation gave a white solid-0.51 g (61 \% yield), which was analyzed by ${ }^{1} \mathrm{H},{ }^{13} \mathrm{C}$, and ${ }^{11} \mathrm{~B}$ NMR spectroscopy and GC/MS. 
IR $\left(\mathrm{cm}^{-1}\right): 3369,2926,2854,1708$.

${ }^{1} \mathrm{H}$ NMR $\left(400 \mathrm{MHz}, \mathrm{CDCl}_{3}, \delta p p m\right): 4.80$ (bs, $\left.1 \mathrm{H}, \mathrm{NH}-\mathrm{COO}\right), 3.64\left(\mathrm{~s}, 3 \mathrm{H}, \mathrm{OCH}_{3}\right), 3.13\left(\mathrm{~m}, 2 \mathrm{H}, \mathrm{J}_{\mathrm{HH}}=\right.$ $\left.7.5 \mathrm{~Hz}, \mathrm{CH}_{2}-\mathrm{NHCO}\right), 1.61$ (m, 2H, $\left.\mathrm{CH}_{2} \mathrm{CH}_{2}-\mathrm{Bpin}\right), 1.24$ (m, 28H, $\left.-\mathrm{CH}_{2}\right), 1.23$ (s, 12H, Bpin), 0.76 (t, $\left.2 \mathrm{H}, J_{\mathrm{HH}}=7.5 \mathrm{~Hz}, \mathrm{CH}_{2}-\mathrm{Bpin}\right)$.

${ }^{13} \mathrm{C}$ NMR (400 MHz, CDCl $\left.3, \delta p p m\right): ~ 155.00\left(\mathrm{NHCO}_{2}\right), 82.74$ (Bpin), $69\left(\mathrm{OCH}_{2}\right) 51.11\left(\mathrm{OCH}_{3}\right), 33.81$ $\left(\mathrm{CH}_{2} \mathrm{CO}_{2} \mathrm{Me}\right), 32.38\left(\mathrm{CH}_{2} \mathrm{CH}_{2}-\mathrm{Bpin}\right), 29.67-28.80\left(-\mathrm{CH}_{2}\right), 24.92$ (Bpin), 24.74 (Bpin), $22.65\left(\mathrm{CH}_{2}-\right.$ Bpin).

${ }^{11} \mathrm{~B}$ NMR (400 MHz, $\left.\mathrm{CDCl}_{3}, \delta \mathrm{ppm}\right): 27 \mathrm{ppm}$.

\section{Oxidation of hydroborated oleyl carbamate using $30 \% \mathrm{H}_{2} \mathrm{O}_{2}$ solution}

Oxidation of hydroborated oleyl carbamate using $30 \% \mathrm{H}_{2} \mathrm{O}_{2}$ solution was performed according to a procedure already reported $[19,26]$.

In a single necked round bottom flask equipped with a magnetic stirrer, a hydroborated oleyl carbamate organoborane solution $(0.5 \mathrm{~g})$ was cooled to $0^{\circ} \mathrm{C}$ and then drop-wise a $3 \mathrm{~N}$ $\mathrm{NaOH}$-solution $(2 \mathrm{~mL})$ and a $30 \% \mathrm{H}_{2} \mathrm{O}_{2}$-solution $(2 \mathrm{~mL})$ were added. After stirring for $3 \mathrm{~h}$ at ambient temperature, water $(10 \mathrm{~mL})$ was added. After saturation with $\mathrm{NaCl}$ salt and separation of the THF-phase, the aqueous phase was extracted with diethyl ether ( $3 \times 15 \mathrm{~mL})$. The combined extract was dried over $\mathrm{MgSO}_{4}$ then the solvent was removed at a rotary evaporator and the product isolated by flash chromatography to afford AB type monomer (I) $0.185 \mathrm{~g}$ (49 \%).

IR (cm $\left.{ }^{-1}\right): 3346,2928,2851,1708,1522,1449,1373,1255,1200,1174,1107,1057,723$

${ }^{1} \mathrm{H} \mathrm{NMR}\left(400 \mathrm{MHz}, \mathrm{CDCl}_{3}, \delta \mathrm{ppm}\right): 4.80$ (bs, $\left.1 \mathrm{H}, \mathrm{NH}-\mathrm{COO}\right), 3.64\left(\mathrm{~s}, 3 \mathrm{H}, \mathrm{OCH}_{3}\right), 3.53\left(\mathrm{t}, 2 \mathrm{H}, \mathrm{J}_{\mathrm{HH}}=6.7\right.$ $\left.\mathrm{Hz}, \mathrm{CH}_{2} \mathrm{OH}\right), 3.13\left(2 \mathrm{H}, \mathrm{m}, \mathrm{J}_{\mathrm{HH}}=7.5 \mathrm{~Hz}, \mathrm{CH}_{2}-\mathrm{NHCO}\right), 1.24(\mathrm{~m}, 28 \mathrm{H},-\mathrm{CH} 2)$. 
${ }^{13} \mathrm{C}$ NMR (400 MHz, CDCl,$\left.\delta p p m\right): 155.00\left(\mathrm{NHCO}_{2}\right), 69\left(\mathrm{CH}_{2} \mathrm{OH}\right), 51.11\left(\mathrm{OCH}_{3}\right), 33.81$

$\left(\mathrm{CH}_{2} \mathrm{CO}_{2} \mathrm{Me}\right), 29.67-28.80\left(\mathrm{CH}_{2}\right)$.

Similarly, same Isomerization-hydroboration-oxidation synthetic strategy was applied for the synthesis of AB-type of monomers (II and III) starting from methyl oleate and oleyl carbonate while AA-type of monomer (IV) from oleyl alcohol, respectively. (see Electronic Supporting Information)

\subsection{General procedure for polymer synthesis: example of polyurethane synthesis}

Into a $100 \mathrm{~mL}$ round-bottom flask equipped with a mineral oil bubbler and a nitrogen inlet, 1 equivalent of AB-type of monomer (I) and $10 \mathrm{~mol} \%$ TBD vs carbamate function were charged. The contents were vigorously stirred at $140{ }^{\circ} \mathrm{C}$ for $24 \mathrm{~h}$ under dynamic vacuum. After appropriate time, the reaction mixture was cooled to room temperature. The polymer was then dissolved in dichloromethane, precipitated in methanol and dried under reduced pressure. The same procedure was followed for the polycondensation of monomers in the cases of polyester and polycarbonate synthesis.

${ }^{1} \mathrm{H}-\mathrm{NMR}\left(400 \mathrm{MHz}, \mathrm{CDCl}_{3}, \delta \mathrm{ppm}\right)$ for polyurethane: $4.12\left(\mathrm{t}, \mathrm{OCH}_{2}\right), 3.21\left(\mathrm{t}, \mathrm{CH}_{2} \mathrm{NH}\right), 1.60-1.52(\mathrm{~m}$, $\left.\mathrm{CH}_{2}\right), 1.21\left(\mathrm{~m}, \mathrm{CH}_{2}\right)$.

\section{Results and discussion}

\subsection{Monomer synthesis}

The Isomerization-Hydroboration-Oxidation strategy was used to introduce omega alcohol functionality on unsaturated fatty acid derivatives. Fig. 1 shows the targeted structures of A-B type monomers (I, II, III) and A-A type diol monomer (IV) for the design of polyurethanes, polyesters and polycarbonates. 


\section{Structure of Monomers}

$$
\text { A-B type monomer }
$$<smiles>COC(=O)NCCCCCCO</smiles>

(I)<smiles>COC(=O)CC(C)CO</smiles><smiles>COC(=O)OCC(C)(C)CO</smiles>

(III)

\section{A-A type monomer}

Di-ol<smiles>CCCCCCO</smiles>

(IV)

Figure 1. Structure of targeted monomers from fatty acid derivatives

The synthesis of $\omega-\mathrm{OH}, \alpha$-carbamatemonomer (I) starting from oleyl amine, by a three-step procedure is described in Scheme 1.

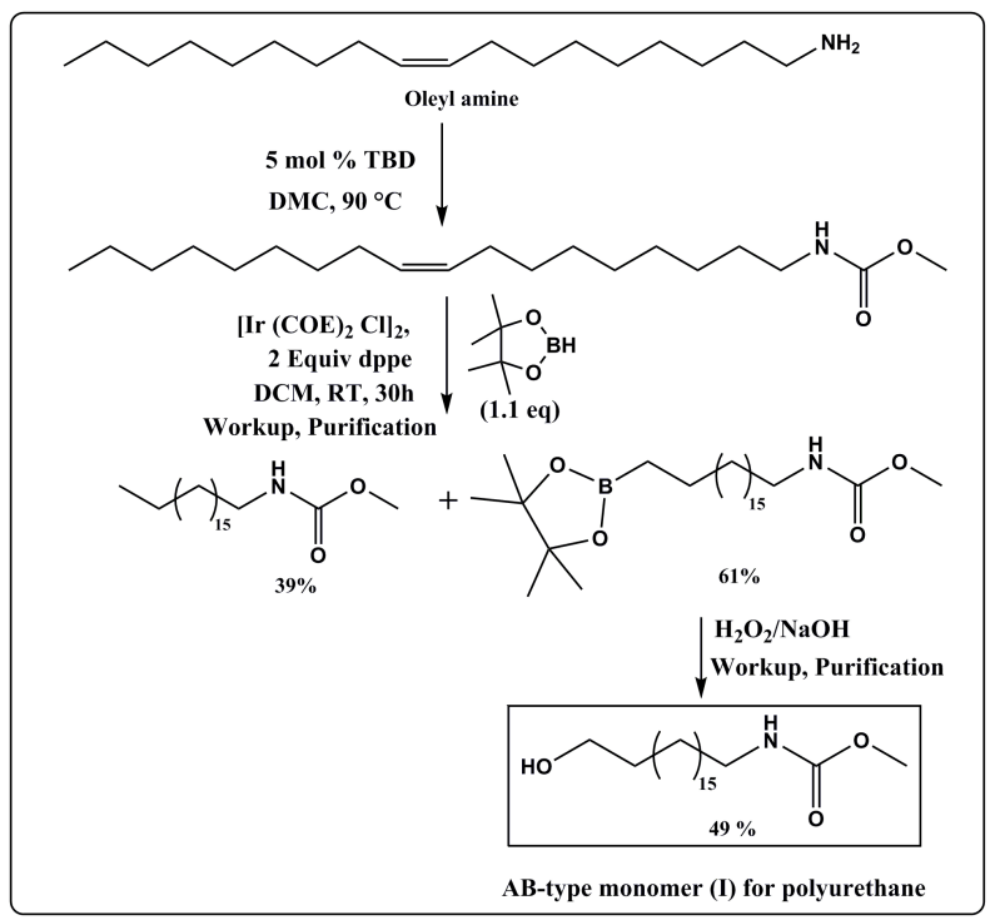

Scheme 1. Synthesis of $\omega$-OH, $\alpha$-carbamate monomer (I) from oleyl amine 
In a first step, oleyl amine in presence of an excess of DMC was quantitatively converted to oleyl carbamate, which was characterized by NMR spectroscopy see Fig. $3 \mathrm{~A}$. In the $2^{\text {nd }}$ step, the isomerization-hydroboration was carried out in dichloromethane from oleyl carbamate in the presence of iridium-based dimer as isomerizing catalyst and subsequently treated with pinacolborane as hindered boronating agent. The reaction product was purified by flash chromatography, isolated and characterized by FT-IR (Fig. 2A), ${ }^{1} \mathrm{H}$ NMR (Fig. 3B) and ${ }^{11} \mathrm{~B} N M R$ spectroscopy (Fig. 4A). One should mention that a side reaction occurs during the isomerizationhydroboration, namely the hydrogenation of the double bond leading to a non-functionalized saturated fatty chain. In the case of oleyl carbamate, this side reaction is important and represents almost $40 \%$ of the total product. In the $3^{\text {rd }}$ step, the oxidation of hydroborated product using $\mathrm{H}_{2} \mathrm{O}_{2}(30 \%)$ in alkaline medium was carried out. The reaction product was isolated after work-up then purified by flash chromatography and characterized by means of FTIR and NMR spectroscopy. The FT-IR spectrum (Fig. 2B) reveals the absorption band corresponding to asymmetric stretching of alcohol functionality at $3350 \mathrm{~cm}^{-1}$ in addition to the strong peak at $1708 \mathrm{~cm}^{-1}$ assigned to the carbonyl carbon of carbamate functionality, thus indicating that urethane functionality is stable under the reaction conditions used.

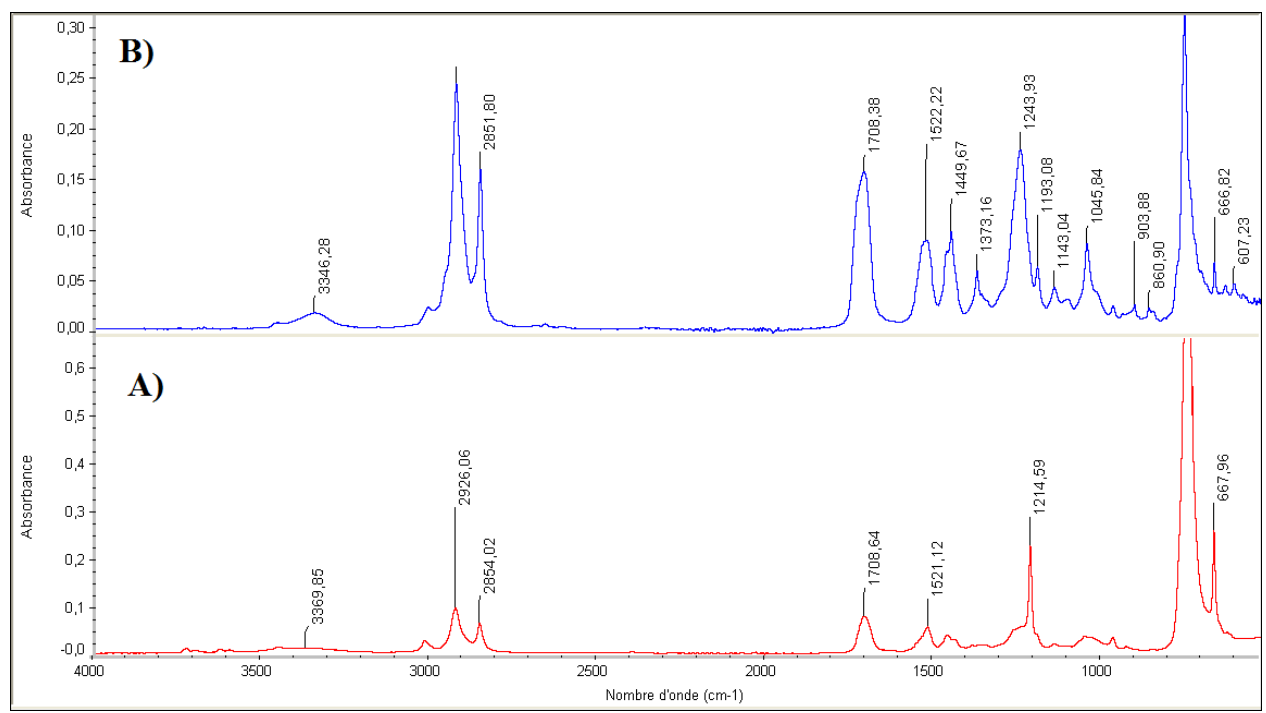


Figure 2. FT-IR spectrum of A) Isomerization-Hydroboration product of oleyl carbamate and B) monomer (I)

The $\omega$-OH, $\alpha$-carbamate monomer (I) was further characterized by NMR spectroscopy. Fig. 3 shows the ${ }^{1} \mathrm{H}$ NMR spectra of all intermediate products along with the corresponding assignments.

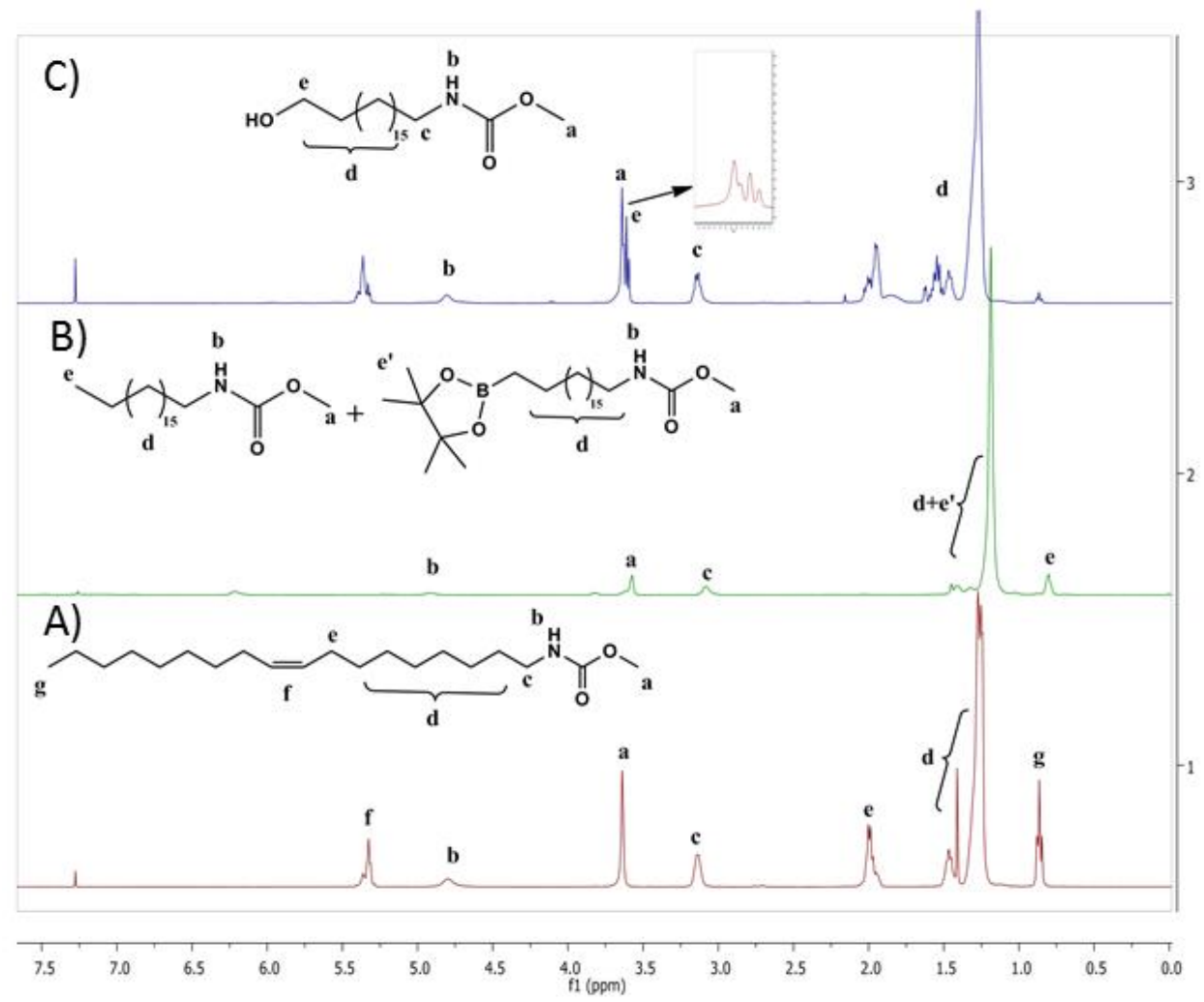

Figure 3. ${ }^{1} \mathrm{H}-\mathrm{NMR}$ spectrum of A) oleyl carbamate B) Isomerization-Hydroboration product of oleyl carbamate C) monomer (I)

The formation of monomer (I) could be proved by NMR spectroscopies. The ${ }^{1} \mathrm{H}-\mathrm{NMR}$ spectrum of monomer(I), (Fig. $3 \mathrm{C}$ ), exhibits a triplet (a) at $3.57 \delta \mathrm{ppm}$, assigned to methylene protons adjacent to the alcohol functionality while ${ }^{11} \mathrm{~B}-\mathrm{NMR}$ (Fig. 4B) spectrum demonstrates the completion of the oxidation process with the disappearance of the peak corresponding to 
borane adduct (see Figure 4). Moreover, the omega functionalization was demonstrated by the disappearance of the methyl proton at $0.88 \mathrm{ppm}$.

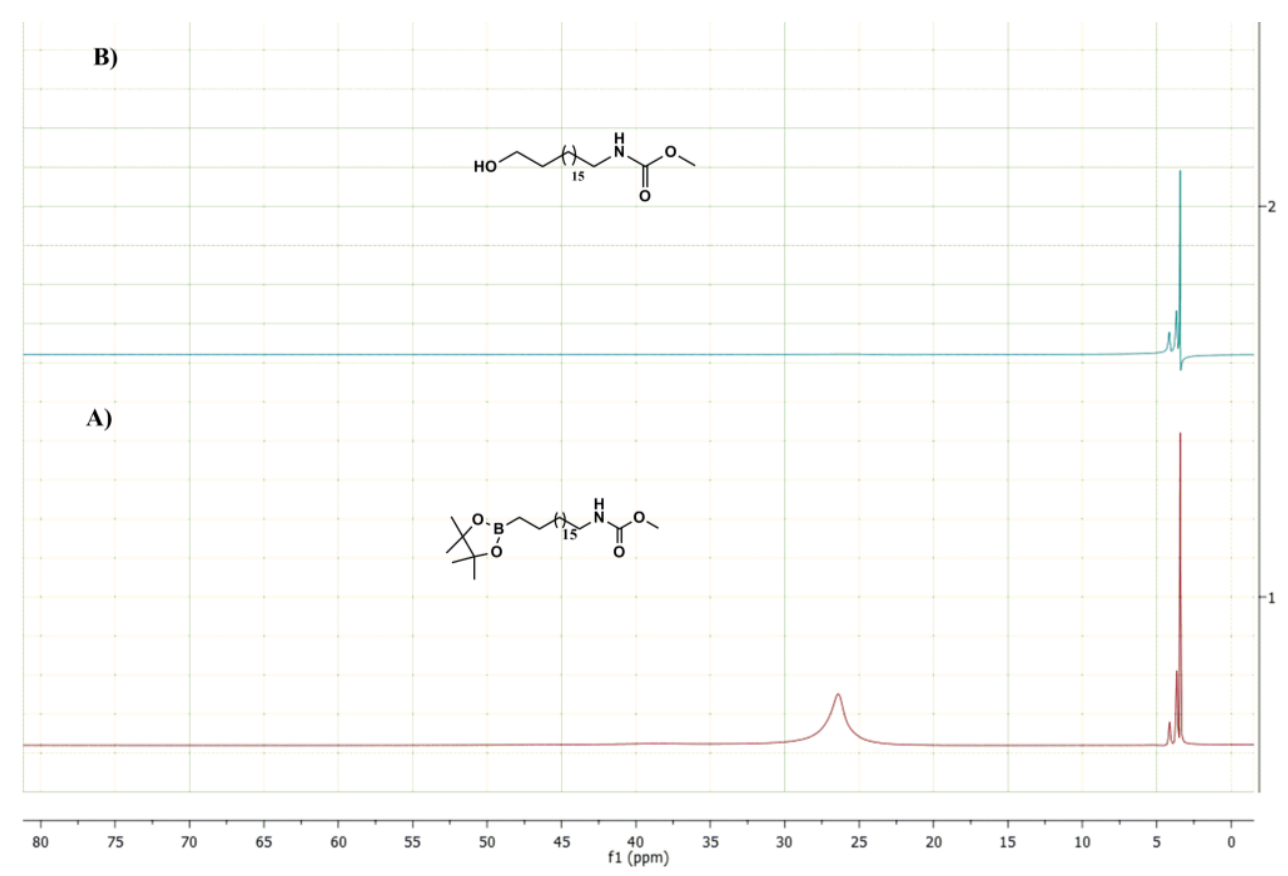

Figure 4. ${ }^{11} \mathrm{~B}-\mathrm{NMR}$ spectrum of A) Isomerization-Hydroboration product of oleyl carbamate

$$
\text { B) monomer (I) }
$$

The monomer (II) and monomer (III) were prepared following the same strategy, i.e isomerization-hydrobration of the methyl oleate and oleyl carbonate respectively followed by the oxidation of the C-B bond (See Electronic Supporting Information). Finally, Scheme 2 shows the synthesis of diol monomer (IV) starting from oleyl alcohol, by a two-step procedure. 


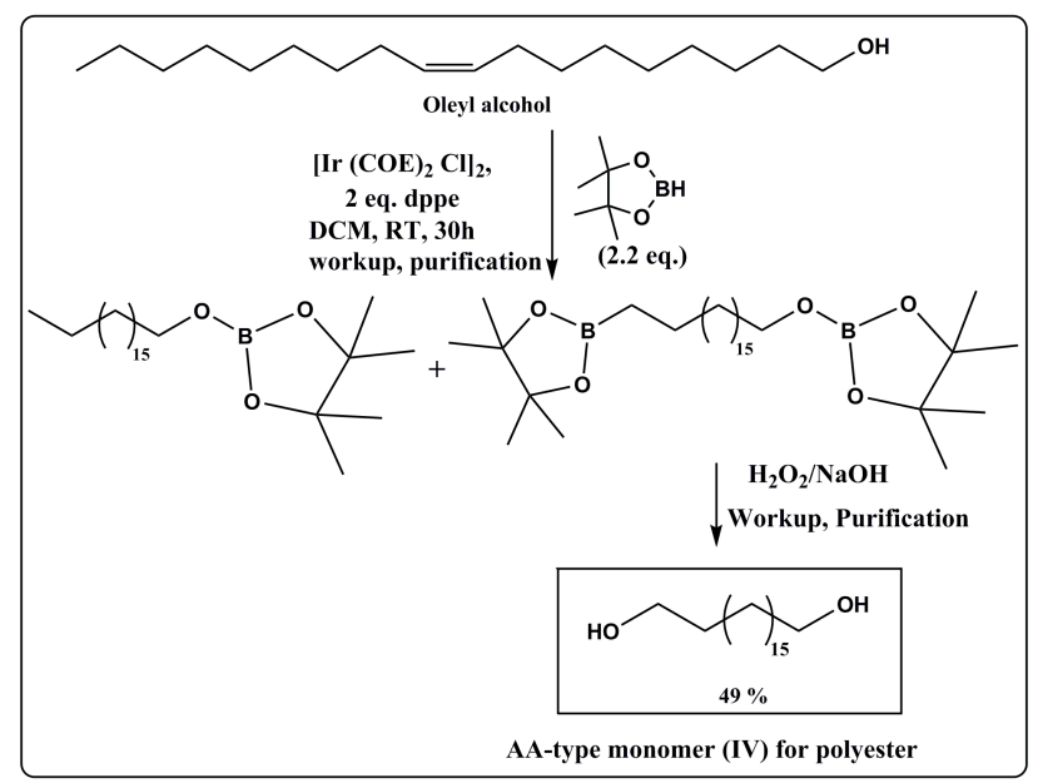

Scheme 2. Synthesis of diol monomer (IV) starting from oleyl alcohol

In this case, as alcohol functions are also susceptible to react with pinacol borane, 2.2 eq. of excess pinacol borane was used. The same strategy as mentioned earlier was followed further for the synthesis of diol monomer (IV). Table 1 gathers the conversion obtained for each intermediate product as well as the final yield in monomer. Whatever the oleyl substituent, the isomerization-hydroboration fully converts the reactant and around $30-40 \%$ of saturated analogue is obtained as side-product from the direct hydrogenation of the double bond. After the two-step procedure, purified monomers are obtained with similar yield, around 50\%. 
Table 1. Different oleyl derivatives used for the synthesis of monomers using IsomerizationHydroboration-Oxidation strategy and the isolated yield obtained

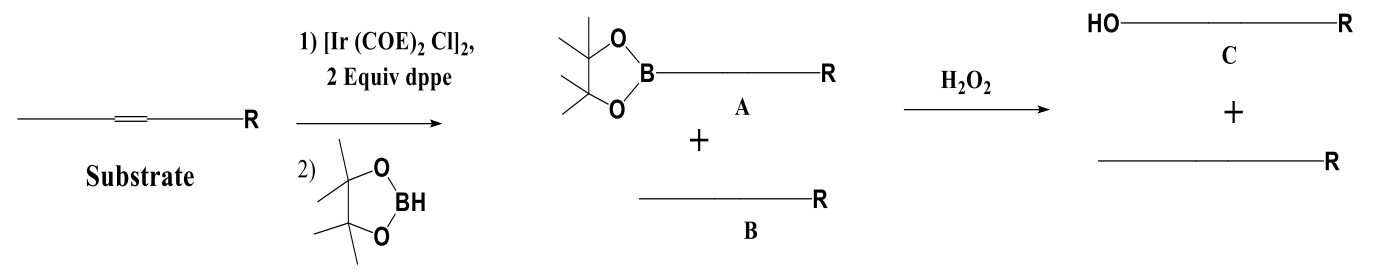

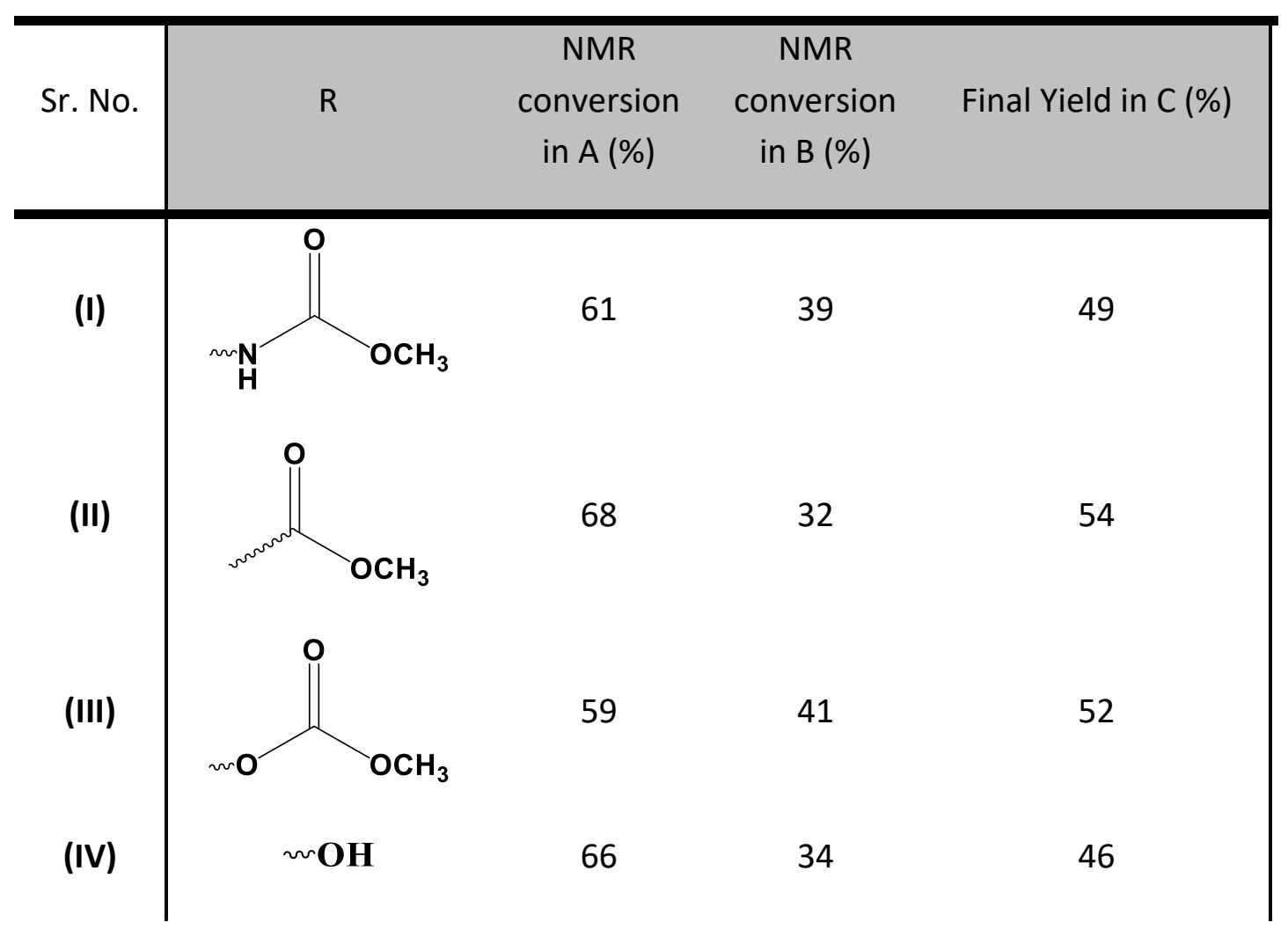

\subsection{Polymer synthesis}

Polyurethanes was prepared by reacting AB-type monomers $\mathbf{I}$ in the presence of $1,5,7$ triazabicyclo[4.4.0]dec-5-ene (TBD) as an organo-catalyst in bulk, as illustrated in Scheme 3. Similar procedure were used to obtain polyesters and polycarbonates by reacting the corresponding AB-type monomers (II and III respectively). TBD was employed as a catalyst due to its high efficiency for transesterification reactions through a dual activation mechanism [27]. 
<smiles>COC(=O)NCCCCCCO</smiles><smiles>C1CN=C2NCCCN2C1</smiles>

$140{ }^{\circ} \mathrm{C}$, vacuum, $24 \mathrm{~h}$<smiles>CCOC(=O)NCCCCCOC(C)(C)C</smiles>

Aliphatic polyurethanes

Scheme 3. Synthesis of polyurethane by transurethanization reaction

All polymerizations were carried out at $140{ }^{\circ} \mathrm{C}$ in the presence of $10 \mathrm{~mol} . \%$ TBD per carbamate function. Dynamic vacuum was applied during the polymerization reaction in order to remove the methanol formed and thus to drive the equilibrium toward the polymer formation. After 24 $\mathrm{h}$ of reaction, the polymers were dissolved in DCM, precipitated in methanol and dried under vacuum. The polymers obtained as white solid materials were characterized by ${ }^{1} \mathrm{H}$ NMR spectroscopy in $\mathrm{CDCl}_{3}$ (Fig. 5).

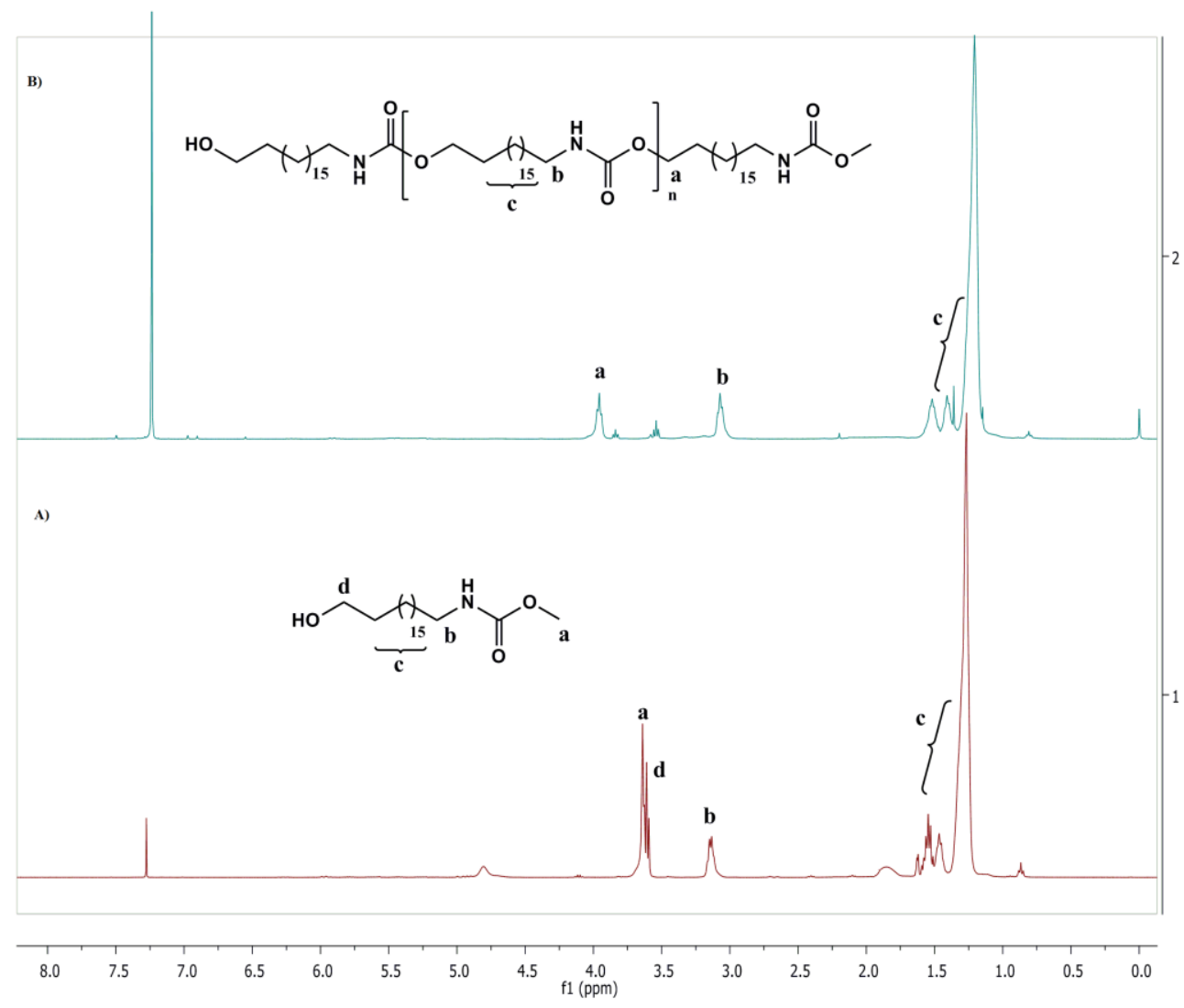


Figure 5. ${ }^{1} \mathrm{H}-\mathrm{NMR}$ spectrum in $\mathrm{CDCl}_{3}$ of $\mathrm{A}$ ) monomer (I) and $\mathrm{B}$ ) of $\mathrm{PU}$ synthesized

In the case of diol monomer (IV), the latter was reacted with two fatty-acid based diesters (A and B), whose synthesis (Electronic Supporting Information Section) was carried out using a reported procedure [24]. The structure of the diesters and the polymerization procedure is depicted in Scheme 4.

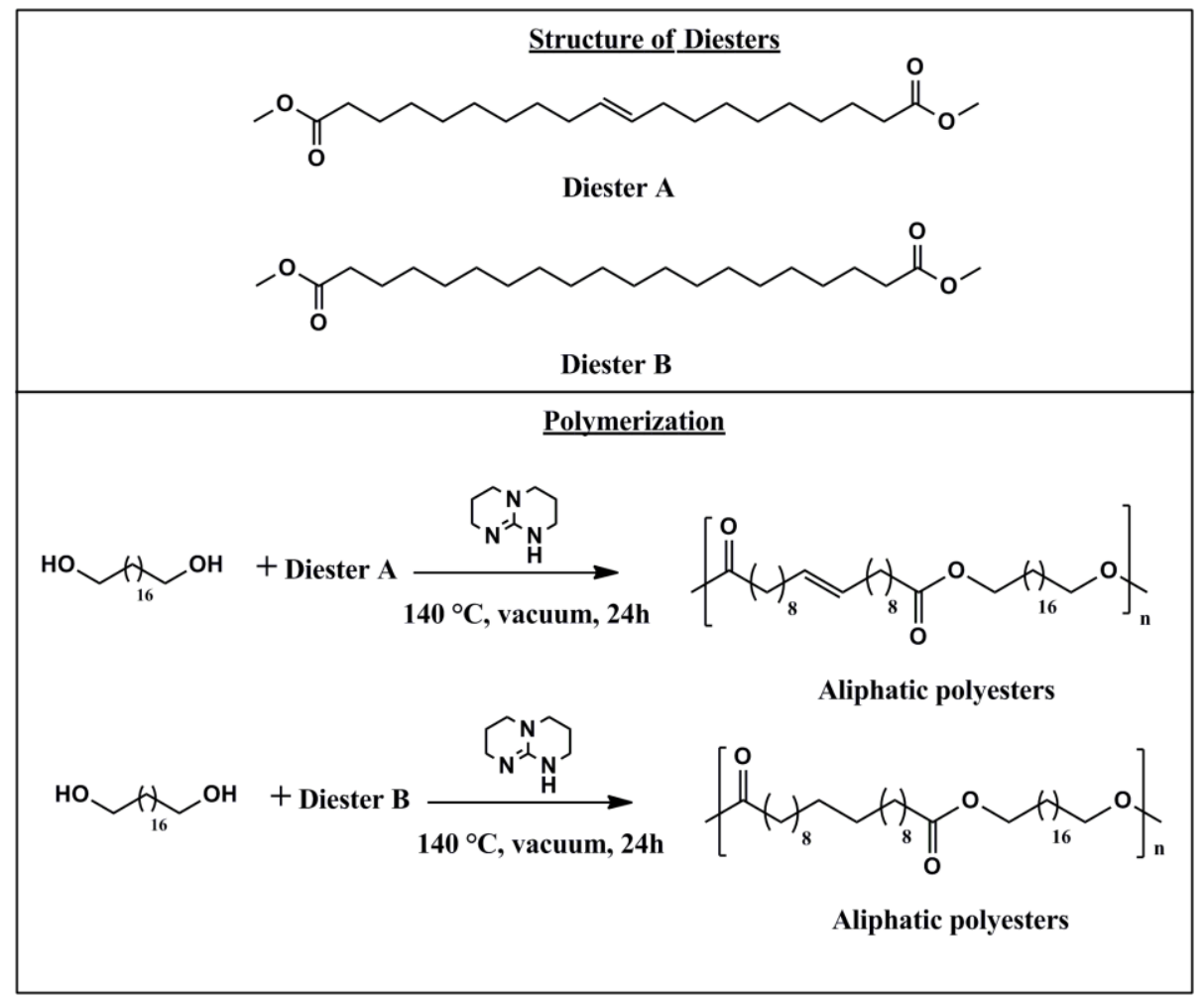

Scheme 4: Structure of the diesters A and B and polyester synthesis.

All the polymer characterization data are given in Table 2. 
Table 2. Synthesis and characterization of polyurethane, polyesters and polycarbonate.

Polymerization performed in bulk at $140^{\circ} \mathrm{C}$ for $24 \mathrm{~h}$ using $10 \% \mathrm{~mol}$ of TBD

\begin{tabular}{|c|c|c|c|c|c|c|c|c|c|c|}
\hline \multirow{2}{*}{$\begin{array}{l}\text { Exp. } \\
\text { No. }\end{array}$} & \multirow{2}{*}{\multicolumn{2}{|c|}{ Monomer }} & \multicolumn{3}{|c|}{$\mathrm{SEC}^{\mathrm{a}}$} & \multicolumn{3}{|c|}{ DSC } & \multicolumn{2}{|c|}{$\mathrm{TGA}^{\mathrm{b}}$} \\
\hline & & & $\begin{array}{c}\mathrm{M}_{\mathrm{n}} \\
\left.\text { (g. } \mathrm{mol}^{-1}\right)\end{array}$ & $\begin{array}{c}\mathrm{M}_{\mathrm{w}} \\
\left(\text { g. } \mathrm{mol}^{-1}\right)\end{array}$ & $\bigoplus$ & $\begin{array}{l}\mathrm{T}_{\mathrm{g}} \\
{ }^{\circ} \mathrm{C}\end{array}$ & $\begin{array}{l}\mathrm{T}_{\mathrm{m}} \\
{ }^{\circ} \mathrm{C}\end{array}$ & $\begin{array}{l}\mathrm{T}_{\mathrm{C}} \\
{ }^{\circ} \mathrm{C}\end{array}$ & $\begin{array}{l}\mathrm{T}_{5} \\
{ }^{\circ} \mathrm{C}\end{array}$ & $\begin{array}{l}\mathrm{T}_{50} \\
{ }^{\circ} \mathrm{C}\end{array}$ \\
\hline 1) & \multicolumn{2}{|c|}{ (I) } & 4500 & 6700 & 1.5 & -25 & 68 & 46 & 217 & 320 \\
\hline 2) & \multicolumn{2}{|c|}{ (II) } & 12300 & 15500 & 1.3 & - & 68 & 56 & 237 & 315 \\
\hline 3) & \multicolumn{2}{|c|}{ (III) } & 8700 & 12500 & 1.4 & -68 & - & - & 189 & 260 \\
\hline 4) & (IV) & (A) & 9300 & 16000 & 1.7 & - & 60 & 52 & 257 & 345 \\
\hline 5) & (IV) & (B) & 11600 & 20400 & 1.8 & - & 78 & 60 & 309 & 420 \\
\hline
\end{tabular}

a) SEC in THF, PS standard. b) $\mathrm{T}_{5}$ - Temperature for $5 \mathrm{wt} \%$ loss; $\mathrm{T}_{50}$ - Temperature for 50 wt $\%$ loss

The molar masses of the polymers formed by auto-condensation of the A-B type monomers (I, II, III) were found rather low - in the range 4500 to $12300 \mathrm{~g} \mathrm{~mol}^{-1}$ with dispersity lower than 2in particular for polyurethane synthesis. This may be explained by the difficulty in removing the by-product $(\mathrm{MeOH})$ formed. Another possibility to explain these low molar masses, is the presence, as impurity in the starting monomers, of the monofunctional saturated adduct which is a side product of the isomerization-hydroboration. In addition the formation of cyclics cannot be excluded [28]. However, the molar mass values provided by SEC are not absolute values as the SEC calibration was carried out using polystyrene standards. The polycondensation of the diol monomer IV with the diesters A and B leads to higher molar mass ( $\mathrm{Mn}$ around $10000 \mathrm{~g} \mathrm{~mol}^{-}$ $\left.{ }^{1}\right)$ polyesters with expected dispersity around 2. 


\subsection{Thermal Characterization}

The thermal stability of the so-formed polymers was studied by TGA under nitrogen atmosphere and the obtained data are given in Table 2 . The $T_{5}$ and $T_{50}$ values are important criteria indicating the thermal stability of the polymers. All polymers exhibited $T_{5}$ above $185^{\circ} \mathrm{C}$. The $T_{5}$ and $T_{50}$ values for polymers were in the range $185-309{ }^{\circ} \mathrm{C}$ and $260-420{ }^{\circ} \mathrm{C}$, respectively. A negligible weight residue at $700{ }^{\circ} \mathrm{C}$ for all polymers was observed, which showed complete decomposition of the polymer backbone.

The thermal properties of the polymers were determined by DSC. Glass transition temperature (Tg) and Melting transition (Tm) values were obtained after second heating scans of polymer samples at a heating rate of $10^{\circ} \mathrm{C} \mathrm{min}^{-1}$. Table 2 displays thermal characteristics of the polymers formed. All polymers, except polycarbonate were semi-crystalline with a melting temperature between 60 and $78^{\circ} \mathrm{C}$. Indeed, the linear nature of the designed monomers and polymers thereof provided chain packing leading to a better organization of the polymer chains, permitting the crystallization.

\section{Conclusion}

In this manuscript, linear long-chain $\alpha, \omega$-difunctional $A B$ - and $A A$-type monomers were synthesized starting from oleyl acid derivatives by transformation of the internal double bond to a terminal alcohol functional group following a 3-step Isomerization-Hydroboration-Oxidation reaction. AB-type monomers were self-condensed by transurethanisation and transesterification reactions in the presence of TBD as an organocatalyst. AA-type diol monomer was polymerized with two fatty acid-based diesters. Thus, linear aliphatic polyesters, 
polycarbonates and polyurethanes were synthesized and characterized by SEC, DSC and TGA. This route to bio-based $\alpha, \omega$-functionalized monomers enables the full incorporation of the fatty acid aliphatic chain in the polymer backbone, leading to materials of interest.

\section{Funding Sources}

This research has been supported by the French Institute for the Energy Transition (Institut pour la Transition Energétique - ITE) P.I.V.E.R.T. (www.institut-pivert.com) selected as an Investment for the Future ("Investissements d'Avenir").

\section{ACKNOWLEDGMENT}

The authors thank University of Bordeaux, Bordeaux INP, CNRS, Aquitaine Regional Council and ITERG for the support of this research. PS thanks the SAS PIVERT for funding. 


\section{References}

[1] Meier, M. A. R., Metzger, J. O., Schubert, U. S., Plant oil renewable resources as green alternatives in polymer science. Chem. Soc. Rev. 2007, 36, 1788-1802.

[2] Gandini A. Polymers from Renewable Resources: A Challenge for the Future of Macromolecular Materials. Macromolecules, 2008, 41, 9491-9504.

[3] Maisonneuve L., Lebarbé T., Grau E., Cramail H. Structure-properties relationship of fatty acid-based thermoplastics as synthetic polymer mimics. Polym. Chem., 2013, 4, 5472-5517

[4] Biermann, U., Bornscheuer, U., Meier, M. A. R., Metzger, J. O., Schäfer, H. J., Oils and Fats as Renewable Raw Materials in Chemistry. Angew. Chem. Int. Ed. 2011, 50, 3854-3871.

[5] Chikkali, S., Mecking, S., Refining of Plant Oils to Chemicals by Olefin Metathesis. Angew .Chem. Int. Ed. 2012, 51, 5802-5808.

[6] Stempfle F., Ortmann P., Mecking S. Long-Chain Aliphatic Polymers To Bridge the Gap between Semicrystalline Polyolefins and Traditional Polycondensates. Chem. Rev., 2016, 116, 4597-4641.

[7] Naughton, F. C., Production, chemistry, and commercial applications of various chemicals from castor oil. J. Am. Oil Chem. Soc. 1974, 51, 65-71.

[8] Genas, M., Rilsan (Polyamid 11), Synthese und Eigenschaften. Angew. Chem. 1962, 74,535-540.

[9] Metzger, J. O., Bornscheuer, U., Lipids as renewable resources: current state of chemical and biotechnological conversion and diversification. Appl. Microbiol. Biotechnol. 2006, 71, 13-22.

[10] Behr, A., Tenhumberg, N., Wintzer, A., Efficient ruthenium-catalysed oxidative cleavage of methyl oleate with hydrogen peroxide as oxidant. RSC Adv. 2013, 3, 172-180.

[11] Behr, A., Westfechtel, A., Pérez G., Catalytic Processes for the Technical Use of Natural Fats and Oils. J. Chem. Eng. Technol. 2008, 31, 700-714.

[12] Roesle, P., Dürr, C. J., Möller, H. M., Cavallo,L., Caporaso, L., Mecking, S., Mechanistic Features of Isomerizing Alkoxycarbonylation of Methyl Oleate. J. Am. Chem. Soc. 2012, 17696-17703.

[13] Rodriguez, C.J., Eastham, G. R., Cole-Hamilton, D. J., Dicarboxylic acid esters from thecarbonylation of unsaturated esters under mild conditions. Inorganic chem. Comm.,2005, 8, 878-881.

[14] Quinzler, D.; Mecking, S. Linear Semicrystalline Polyesters from Fatty Acids by Complete Feedstock Molecule Utilization. Angew. Chem., Int. Ed. 2010, 49, 4306-4308.

[15] Kranenburg, M., Van der Burgt, Y. E. M., Kamer, P. C. J., Van Leeuwen, P. W. N. M., Goubitz, K., Fraanje, J., New Diphosphine Ligands Based on Heterocyclic Aromatics Inducing Very High Regioselectivity in Rhodium-Catalyzed Hydroformylation: Effect of the Bite Angle. Organometalics 1995, 14, 3081-3089.

[16] Vander Veen, L., Kamer, A. P. C. J., Van Leeuwen, P. W. N. M., Hydroformylation of Internal Olefins to Linear Aldehydes with Novel Rhodium Catalysts. Angew. Chem. Int. Ed. 1999, 38, 336-338. 
[17] Ahmed, M., Bronger, R. P. J., Jackstell, R., Kamer, P. C. J., Van Leeuwen, P. W. N. M., Beller, M., Plant oil renewable resources as green alternatives in polymer science. Chem. Eur. J. 2006, 12, 8979-8988.

[18] Hart, D. W., Schwartz, J., Hydrozirconation. Organic synthesis via organozirconium intermediates. Synthesis and rearrangement of alkylzirconium(IV) complexes and their reaction with electrophiles. J. Am. Chem. Soc. 1974, 96, 8115-8116.

[19] Lucas, T., Schäfer, H. J., Hydroboration of unsaturated fatty acid methyl esters and conversion of the boron adducts. Eur. J. Lipid Sci. Technol. 2014, 116, 52-62.

[20] Ghebreyessus, K. Y., Angelici, R. J., Isomerizing-Hydroboration of the Monounsaturated Fatty Acid Ester Methyl Oleate. Organometallics, 2006, 25, 3040-3044.

[21] Maisonneuve, L., Wirotius, A. L., Alfos, C., Grau, E., Cramail, H. Fatty acid-based (bis) 6membered cyclic carbonates as efficient isocyanate free poly (hydroxyurethane) precursors, Polym. Chem., 2014, 5, 6142-6147

[22] Lebarbé, T., More, A. S., Sane, P. S., Grau, E., Alfos, C., Cramail, H., Bio-Based Aliphatic Polyurethanes Through ADMET Polymerization in Bulk and Green Solvent. Macromol. Rapid Commun. 2014, 35, 479-483.

[23] Lebarbé, T., Neqal, M., Grau, E., Alfos, C., Cramail, H., Branched polyethylene mimicry by metathesis copolymerization of fatty acid-based $\alpha, \omega$-dienes. Green Chem. 2014, 16, 1755-1758.

[24] Lebarbe, T., Maisonneuve, L., Nguyen, T. H., Gadenne, B., Alfos, C., Cramail, H., Methyl 10-undecenoate as a raw material for the synthesis of renewable semicrystalline polyesters and poly(ester-amide)s, Polym. Chem., 2012,3, 2842-2851.

[25] More, A. S., Palaskar, D. V., Cloutet, E., Gadenne, B., Alfos, C., Cramail, H., Aliphatic polycarbonates and poly(ester carbonate)s from fatty acid derived monomers. Polym. Chem., 2011, 2, 2796-2803.

[26] Kabalka, G. W., Wadgaonkar, P. P., Chatla, N., An operationally simple hydroborationoxidation experiment. J. Chem. Edu. 1990, 67, 975-976.

[27] Kiesewetter, M. K., Shin, E. J., Hedrick, J. L., Waymouth, R. M. Organocatalysis: Opportunities and Challenges for Polymer Synthesis Macromolecules, 2010, 43, 20932107.

[28] Palaskar, D.V., Boyer, A., Cloutet, E., Alfos, C., Cramail, H. Synthesis of Biobased Polyurethane from Oleic and Ricinoleic Acids as the Renewable Resources via the $A B-$ Type Self-Condensation Approach. Biomacromolecules. 2010, 11(5), 1202-1211. 


\section{TOC}

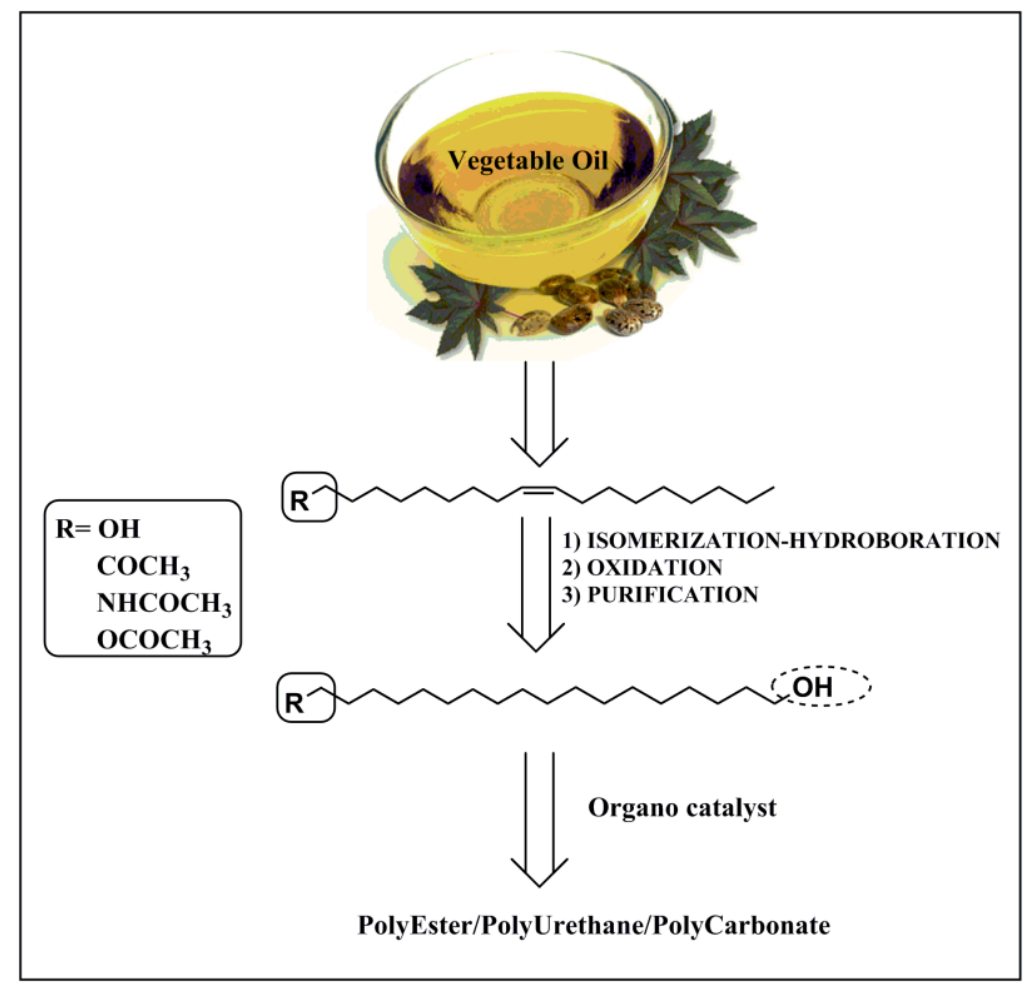




\title{
Supporting Information
}

\section{Isomerization-Hydroboration-Oxidation Strategy: Access to Long Chain AB- and}

\author{
AA-type Oleyl Based Monomers and Polymers Thereof \\ Prakash Sane ${ }^{a, b}$ Thomas Lebarbéc, Etienne Grau, ${ }^{a, b}$ and Henri Cramail $a, b$ *
}

\section{A Synthesis of AB-type monomer (II) for aliphatic polyesters Isomerization-Hydroboration}

The procedure for Isomerization-Hydroboration of methyl oleate was followed as reported by Angelici et al. [20]

A two-necked round bottom flask equipped with a magnetic stirrer was charged with $\left[\operatorname{Ir}(\mathrm{COE})_{2} \mathrm{Cl}\right]_{2}(0.030 \mathrm{~g}, 0.033 \mathrm{mmol})$ and 1,2-bis(diphenylphosphino)ethane (dppe) (0.027 g, $0.066 \mathrm{mmol}$ ) under an argon flow. Methylene chloride $(3 \mathrm{~mL})$ was added to give a clear orange solution, which was stirred for $5 \mathrm{~min}$. To this solution were added methyl oleate $(0.3 \mathrm{~g}, 1.0$ $\mathrm{mmol}$ ) and pinacolborane $(0.175 \mathrm{~mL}, 1.2 \mathrm{mmol})$, then the reaction mixture was stirred for $24 \mathrm{~h}$ at room temperature. The resulting light yellow solution was diluted with $100 \mathrm{~mL}$ of methylene chloride and filtered through silica gel to remove the catalyst. The filtrate was then evaporated under reduced pressure to give a white solid, which was analyzed by ${ }^{1} \mathrm{H},{ }^{13} \mathrm{C}$, and ${ }^{11} \mathrm{~B}$ NMR spectroscopy and GC/MS. Below are data for (Bpin)- $\left(\mathrm{CH}_{2}\right)_{17}-\mathrm{CO}_{2} \mathrm{Me} 0.29 \mathrm{~g}$ (68\% yield). The other major product was hydrogenated product of methyl oleate $0.13 \mathrm{~g}(32 \%)$, which was identified by GC/MS.

${ }^{1} \mathrm{H}$ NMR $\left(400 \mathrm{MHz}, \mathrm{CDCl}_{3}, 25^{\circ} \mathrm{C}\right): 3.65$ (s, 3H, OMe), 2.28 (t, $\left.2 \mathrm{H}, \mathrm{CH}_{2} \mathrm{CO}_{2} \mathrm{Me}\right), 1.61(\mathrm{~m}, 2 \mathrm{H}$, $\left.\mathrm{CH}_{2} \mathrm{CH}_{2}-\mathrm{Bpin}\right), 1.24\left(\mathrm{~m}, 28 \mathrm{H},-\mathrm{CH}_{2}-\right), 1.23(\mathrm{~s}, 12 \mathrm{H}, \mathrm{Bpin}), 0.76\left(\mathrm{t}, \mathrm{J}_{\mathrm{HH}}=7.5 \mathrm{~Hz}, 2 \mathrm{H}, \mathrm{CH}_{2}-\mathrm{Bpin}\right)$. 
${ }^{13} \mathrm{C} \mathrm{NMR}\left(400 \mathrm{MHz}, \mathrm{CDCl}_{3}, 25^{\circ} \mathrm{C}\right): 174.00$ (C=O), 82.74 (Bpin), 51.11 (OMe), $33.81\left(\mathrm{CH}_{2} \mathrm{CO}_{2} \mathrm{Me}\right)$, $32.38\left(\mathrm{CH}_{2} \mathrm{CH}_{2}-\mathrm{Bpin}\right), 29.67-28.80\left(-\mathrm{CH}_{2}-\right), 24.92$ (Bpin), 24.74 (Bpin), 22.65 (CH2-Bpin).

${ }^{11} \mathrm{~B}$ NMR $\left(400 \mathrm{MHz}, \mathrm{CDCl}_{3}, 25^{\circ} \mathrm{C}\right): 30.01 \mathrm{ppm}$.

\section{Oxidation of Hydroborated methyl oleate using $30 \% \mathrm{H}_{2} \mathrm{O}_{2}$ solution}

Oxidation of Hydroborated methyl oleate using $30 \% \mathrm{H}_{2} \mathrm{O}_{2}$ solution was performed according to a procedure already reported $[19,26]$.

Into a single necked round bottom flask equipped with a magnetic stirrer, an organoborane solution was cooled to $0^{\circ} \mathrm{C}$ and then $2 \mathrm{~mL}$ of a $3 \mathrm{~N} \mathrm{NaOH}$ solution and $2 \mathrm{~mL}$ of a $30 \% \mathrm{H}_{2} \mathrm{O}_{2}$ solution was added drop-wise. After stirring for $1 \mathrm{~h}$ at RT, water $(10 \mathrm{~mL})$ was added. After saturation with $\mathrm{NaCl}$ salt and separation of THF, the aqueous phase was extracted with diethyl ether $(3 \mathrm{X} 15 \mathrm{~mL})$. The combined extract was dried $\left(\mathrm{MgSO}_{4}\right)$, the solvent was removed at a rotary evaporator and the product was isolated by flash chromatography to afford monomer (II)-0.115 g (54\%).

IR (cm $\left.{ }^{-1}\right):$ 3369, 2928, 2856, 1741 1458, 1438, 1364, 1255, 1200, 1174, 1107, 1057, 723 (m).

${ }^{1} \mathrm{H} \mathrm{NMR}\left(\mathrm{CDCl}_{3}\right): 3.61(\mathrm{~s}, 3 \mathrm{H}, \mathrm{OMe}), 3.53\left(\mathrm{t}, 2 \mathrm{H}, \mathrm{J}_{\mathrm{HH}}=6.7 \mathrm{~Hz} \mathrm{CH}_{2} \mathrm{OH}\right), 2.25$ (bs, $\left.1 \mathrm{H}, \mathrm{OH}\right), 2.18(\mathrm{t}$, $\left.2 \mathrm{H}, J_{\mathrm{HH}}=7.5 \mathrm{HzCH} \mathrm{CO}_{2} \mathrm{Me}\right), 1.54\left(\mathrm{t}, 2 \mathrm{H},-\mathrm{CH}_{2}-\right), 1.46\left(\mathrm{t}, 2 \mathrm{H},-\mathrm{CH}_{2}-\right), 1.24\left(\mathrm{~m}, 26 \mathrm{H},-\mathrm{CH}_{2}-\right)$,

${ }^{13} \mathrm{C} \mathrm{NMR}\left(\mathrm{CDCl}_{3}\right): 174.00(\mathrm{C}=\mathrm{O}), 62\left(\mathrm{CH}_{2} \mathrm{OH}\right), 51.11$ (OMe), $33.81\left(\mathrm{CH}_{2} \mathrm{CO}_{2} \mathrm{Me}\right), 32.38,29.67-$ $28.80\left(-\mathrm{CH}_{2-}\right)$,

\section{B Synthesis of AB-type monomer for aliphatic polycarbonate (III)}

\section{Synthesis of Oleyl carbonate}

Into a two necked round bottom flask equipped with a magnetic stirrer, a mixture of oleyl alcohol (10 g, $37.24 \mathrm{mmol}$ ) and TBD (0.0370 g, $0.1489 \mathrm{mmol}, 0.5 \mathrm{~mol} \%$ based on oleyl alcohol) 
was stirred at $70{ }^{\circ} \mathrm{C}$ under nitrogen atmosphere. After 10 minutes, excess $\mathrm{DMC}(30 \mathrm{~mL})$ was added and the reaction mixture was heated at $90^{\circ} \mathrm{C}$ for $5 \mathrm{~h}$. The excess of DMC was removed by distillation and the reaction mixture was taken into dichloromethane (DCM) (100 mL). The DCM solution was washed with water ( $3 \times 40 \mathrm{~mL})$, followed by brine solution $(1 \times 40 \mathrm{~mL})$. The DCM solution was dried over anhydrous sodium sulfate, and filtered through a pad of Celite. The removal of solvent yielded oleyl carbonate, as pale yellow oil. (10.89 g, yield: $90 \%)$.

IR $\left(\mathrm{cm}^{-1}\right): 1750$ (-OCOO).

${ }^{1} \mathrm{H}-\mathrm{NMR}\left(400 \mathrm{MHz}, \mathrm{CDCl}_{3}\right): 5.34(2 \mathrm{H}, \mathrm{m}, \mathrm{CH}=\mathrm{CH}) .4 .13\left(2 \mathrm{H}, \mathrm{q}, \mathrm{J}_{\mathrm{HH}}=7.1 \mathrm{~Hz}, \mathrm{CH}_{2}-\mathrm{OCOO}-\mathrm{CH}_{3}\right), 3.76$

$\left(3 \mathrm{H}, \mathrm{s}, \mathrm{CH}_{2}-\mathrm{OCOO}-\mathrm{CH}_{3}\right), 2.02\left(4 \mathrm{H}, \mathrm{m}, \mathrm{CH}_{2}-\mathrm{CH}=\mathrm{CH}-\mathrm{CH}_{2}\right), 1.59\left(2 \mathrm{H}, \mathrm{q}, \mathrm{CH}_{2}-\mathrm{CH}_{2} \mathrm{OCOO}\right), 1.40-1.10$ (methylene protons), $0.88\left(3 \mathrm{H}, \mathrm{s}, \mathrm{CH}_{3}\right)$.

${ }^{13} \mathrm{C} \mathrm{NMR}\left(400 \mathrm{MHz}, \mathrm{CDCl}_{3}, 25{ }^{\circ} \mathrm{C}\right): 156.00\left(\mathrm{OCO}_{2}\right), 131(\mathrm{CH}=\mathrm{CH}), 69\left(\mathrm{OCH}_{2}\right) 51.11(\mathrm{OMe}), 33.81$ $\left(\mathrm{CH}_{2} \mathrm{CO}_{2} \mathrm{Me}\right)$, 29.67-28.80 (- $\left.\mathrm{CH}_{2}-\right), 13.21\left(-\mathrm{CH}_{3}\right)$.

\section{Isomerization-Hydroboration-Oxidation of Oleyl carbonate Isomerization-Hydroboration}

Procedure for Isomerization-Hydroboration of Oleyl carbonate was followed as reported by Angelici et al [20].

A two necked round bottom flask equipped with a magnetic stirrer, was charged with $\left[\operatorname{Ir}(\mathrm{COE})_{2} \mathrm{Cl}\right]_{2}(0.030 \mathrm{~g}, 0.033 \mathrm{mmol})$ and 1,2-bis(diphenylphosphino)ethane (dppe) (0.027 g, $0.066 \mathrm{mmol}$ ) under an argon flow. Methylene chloride $(3 \mathrm{~mL})$ was added to give a clear orange solution, which was stirred for $5 \mathrm{~min}$. To this solution were added oleyl carbonate $(0.32 \mathrm{~g}, 1.0$ $\mathrm{mmol})$ and pinacolborane $(0.175 \mathrm{~mL}, 1.2 \mathrm{mmol})$ and the reaction mixture was stirred for $24 \mathrm{~h}$ at 
room temperature. The resulting light yellow solution was diluted with $100 \mathrm{~mL}$ of methylene chloride and filtered through silica gel to remove the catalyst. The filtrate was then evaporated under reduced pressure to give a white solid ( $0.26 \mathrm{~g}$, yield: $59 \%)$, which was analyzed by ${ }^{1} \mathrm{H}$, ${ }^{13} \mathrm{C}$, and ${ }^{11} \mathrm{~B}$ NMR spectroscopy and GC/MS. Below are data for (Bpin)- $\left(\mathrm{CH}_{2}\right){ }_{17}-\mathrm{OCO}_{2} \mathrm{Me}$.

IR ( $\left(\mathrm{cm}^{-1}\right): 1747$ (-OCOO).

${ }^{1} \mathrm{H} \mathrm{NMR}\left(400 \mathrm{MHz}, \mathrm{CDCl}_{3}, 25^{\circ} \mathrm{C}\right): 4.03\left(2 \mathrm{H}, \mathrm{q}, \mathrm{J}_{\mathrm{HH}}=7.1 \mathrm{~Hz}, \mathrm{CH}_{2}-\mathrm{OCOO}-\mathrm{CH} 3\right), 3.71(\mathrm{~s}, 3 \mathrm{H}, \mathrm{OMe})$, $1.61\left(\mathrm{~m}, 2 \mathrm{H}, \mathrm{CH}_{2} \mathrm{CH}_{2}-\mathrm{Bpin}\right), 1.24(\mathrm{~m}, 28 \mathrm{H},-\mathrm{CH} 2-), 1.23(\mathrm{~s}, 12 \mathrm{H}, \mathrm{Bpin}), 0.76\left(\mathrm{t}, 2 \mathrm{H}, \mathrm{J}_{\mathrm{HH}}=7.5 \mathrm{~Hz}\right.$, $\mathrm{CH}_{2}$-Bpin).

${ }^{13} \mathrm{C}$ NMR $\left(400 \mathrm{MHz}, \mathrm{CDCl}_{3}, 25^{\circ} \mathrm{C}\right): 155.00\left(\mathrm{OCO}_{2}\right), 82.74(\mathrm{Bpin}), 69\left(\mathrm{OCH}_{2}\right) 51.11$ (OMe), 33.81 $\left(\mathrm{CH}_{2} \mathrm{CO}_{2} \mathrm{Me}\right), 32.38\left(\mathrm{CH}_{2} \mathrm{CH}_{2}-\mathrm{Bpin}\right)$, 29.67-28.80 $\left(-\mathrm{CH}_{2}-\right), 24.92$ (Bpin), 24.74 (Bpin), $22.65\left(\mathrm{CH}_{2-}\right.$ Bpin).

${ }^{11} \mathrm{~B}$ NMR $\left(400 \mathrm{MHz}, \mathrm{CDCl}_{3}, 25^{\circ} \mathrm{C}\right): 38.01 \mathrm{ppm}$.

\section{Oxidation of Hydroborated Oleyl carbonate using $30 \% \mathrm{H}_{2} \mathrm{O}_{2}$ solution}

Oxidation of Oleyl carbonate using $30 \% \mathrm{H}_{2} \mathrm{O}_{2}$ solution was performed according to procedure already reported $[19,26]$.

Into a single necked round bottom flask equipped with a magnetic stirrer, organoborane solution was cooled to $0^{\circ} \mathrm{C}$ and then dropwise $2 \mathrm{~mL}$ of a $3 \mathrm{~N} \mathrm{NaOH}$ solution and $2 \mathrm{~mL}$ of a $30 \%$ $\mathrm{H}_{2} \mathrm{O}_{2}$ solution was added. After stirring for $1 \mathrm{~h}$ at $\mathrm{RT}$, water $(10 \mathrm{~mL})$ was added. After saturation with $\mathrm{NaCl}$ and separation of the THF-phase, the aqueous phase was extracted with diethyl ether (3X15 mL). The combined extract was dried over $\mathrm{MgSO}_{4}$, the solvent was removed at a rotary 
evaporator and the product was isolated by flash chromatography to afford monomer III (0.126 g, yield: $52 \%)$.

IR (cm $\left.{ }^{-1}\right): 3369,2928,2856,1747,1458,1438,1364,1255,1200,1174,1107,1057,723$ (m).

${ }^{1} \mathrm{H} \mathrm{NMR}\left(\mathrm{CDCl}_{3}\right): 4.03\left(2 \mathrm{H}, \mathrm{q}, J_{\mathrm{HH}}=7.1 \mathrm{~Hz}, \mathrm{CH}_{2}-\mathrm{OCOO}-\mathrm{CH}_{3}\right), 3.61(\mathrm{~s}, 3 \mathrm{H}, \mathrm{OMe}), 3.53\left(\mathrm{t}, 2 \mathrm{H}, J_{\mathrm{HH}}=\right.$ $6.5 \mathrm{~Hz}, \mathrm{CH}_{2} \mathrm{OH}$ ), $2.28\left(\mathrm{t}, 2 \mathrm{H}, J_{\mathrm{HH}}=7.5 \mathrm{~Hz}, \mathrm{CH}_{2} \mathrm{CO}_{2} \mathrm{Me}\right.$ ), 2.15 (bs, $\left.1 \mathrm{H}, \mathrm{OH}\right), 1.62\left(\mathrm{~m}, 2 \mathrm{H},-\mathrm{CH}_{2}\right) 1.24$ $\left(\mathrm{m}, 28 \mathrm{H},-\mathrm{CH}_{2}-\right)$,

${ }^{13} \mathrm{C} \mathrm{NMR}\left(\mathrm{CDCl}_{3}\right): 155.00\left(\mathrm{OCO}_{2}\right), 69\left(\mathrm{CH}_{2} \mathrm{OH}\right), 68\left(\mathrm{COOCH}_{2}\right), 51.11(\mathrm{OMe}), 33.81\left(\mathrm{CH}_{2} \mathrm{CO}_{2} \mathrm{Me}\right)$, 29.67-28.80 (- $\left.\mathrm{CH}_{2-}-\right)$,

\section{Synthesis A-A diol monomers (IV) for polyester synthesis} Isomerization-hydroboration

Procedure for Isomerization-Hydroboration of Oleyl alcohol was followed as reported by Angelici et al. [20]

A two-necked round bottom flask equipped with a magnetic stirrer was charged with $\left[\operatorname{Ir}(\mathrm{COE})_{2} \mathrm{Cl}\right]_{2}(0.030 \mathrm{~g}, 0.033 \mathrm{mmol})$ and 1,2-bis(diphenylphosphino)ethane (dppe) (0.027 $\mathrm{g}$, $0.066 \mathrm{mmol}$ ) under an argon flow. Methylene chloride $(3 \mathrm{~mL})$ was added to give a clear orange solution, which was stirred for $5 \mathrm{~min}$. To this solution were added Oleyl alcohol $(0.27 \mathrm{~g}, 1.0$ $\mathrm{mmol})$ and pinacolborane $(0.175 \mathrm{~mL}, 2.0 \mathrm{mmol})$ and the reaction mixture was stirred for $24 \mathrm{~h}$ at room temperature. The resulting light yellow solution was diluted with $100 \mathrm{~mL}$ of methylene chloride and filtered through silica gel to remove the catalyst. The filtrate was then evaporated under reduced pressure to give a white solid $(0.33 \mathrm{~g}$, yield: $66 \%)$., which was analyzed by ${ }^{1} \mathrm{H}$, ${ }^{13} \mathrm{C}$, and ${ }^{11} \mathrm{~B}$ NMR spectroscopy and GC/MS. 
${ }^{1} \mathrm{H}$ NMR (400 MHz, $\left.\mathrm{CDCl}_{3}, 25^{\circ} \mathrm{C}\right): 3.83\left(2 \mathrm{H}, \mathrm{t}, \mathrm{CH}_{2}-\mathrm{OBpin}\right), 1.61\left(2 \mathrm{H}, \mathrm{m}, \mathrm{CH}_{2} \mathrm{CH}_{2}-\mathrm{Bpin}\right), 1.24(28 \mathrm{H}$, m, $-\mathrm{CH} 2-), 1.23$ (s, 12H, Bpin), 0.76 (2H, t, $\left.\mathrm{CH}_{2}-\mathrm{Bpin}\right)$.

${ }^{13} \mathrm{C}$ NMR $\left(400 \mathrm{MHz}, \mathrm{CDCl}_{3}, 25^{\circ} \mathrm{C}\right): 82.74$ (Bpin), $69\left(\mathrm{OCH}_{2}\right), 33.81\left(\mathrm{CH}_{2} \mathrm{CO}_{2} \mathrm{Me}\right), 32.38\left(\mathrm{CH}_{2} \mathrm{CH}_{2-}\right.$ Bpin), 29.67-28.80 (-CH $\left.2^{-}\right), 24.92$ (Bpin), 24.74 (Bpin), $22.65\left(\mathrm{CH}_{2}-\mathrm{Bpin}\right)$.

${ }^{11} \mathrm{~B}$ NMR $\left(400 \mathrm{MHz}, \mathrm{CDCl}_{3}, 25^{\circ} \mathrm{C}\right): 26.46 \mathrm{ppm}$.

\section{Oxidation of Hydroborated Oleyl alcohol using $30 \% \mathrm{H}_{2} \mathrm{O}_{2}$ solution}

Oxidation of hydroborated Oleyl alcohol using $30 \% \mathrm{H}_{2} \mathrm{O}_{2}$ solution was followed as reported previously. $[19,26]$

Into a single necked round bottom flask equipped with a magnetic stirrer, organoborane solution $(0.33 \mathrm{~g})$ was cooled to $0^{\circ} \mathrm{C}$ and then dropwise $2 \mathrm{~mL}$ of a $3 \mathrm{~N}-\mathrm{NaOH}$ solution and $2 \mathrm{~mL}$ of a $30 \% \mathrm{H}_{2} \mathrm{O}_{2}$ solution were added. After stirring for $1 \mathrm{~h}$ at $\mathrm{RT}$, water $(10 \mathrm{~mL})$ was added. After saturation with $\mathrm{NaCl}$ and separation of the THF-phase, the aqueous phase was extracted with diethyl ether (3X15 mL). The combined extract was dried over $\mathrm{MgSO}_{4}$, the solvent was removed at a rotary evaporator and the product was isolated by flash chromatography to afford monomer IV (0.09 g, yield: $46 \%)$.

IR (cm $\left.{ }^{-1}\right):$ 3369, 2928, 2856, 1741 1458, 1438, 1364, 1255, 1200, 1174, 1107, 1057, 723 (m).

${ }^{1} \mathrm{H}$ NMR (400 MHz, $\left.\mathrm{CDCl}_{3}, 25^{\circ} \mathrm{C}\right): 3.50\left(\mathrm{t}, \mathrm{CH}_{2}-\mathrm{OH}\right), 1.54\left(\mathrm{~m},-\mathrm{CH}_{2}\right), 1.24\left(28 \mathrm{H}, \mathrm{m},-\mathrm{CH}_{2}-\right)$.

${ }^{13} \mathrm{C} \mathrm{NMR}\left(400 \mathrm{MHz}, \mathrm{CDCl}_{3}, 25^{\circ} \mathrm{C}\right): 62\left(\mathrm{OCH}_{2}\right), 33.81\left(\mathrm{CH}_{2} \mathrm{CH}_{2} \mathrm{OH}\right), 29.67-28.80\left(-\mathrm{CH}_{2}-\right)$,

\section{Synthesis of Diesters for polyester synthesis}

\section{Synthesis of dimethyl 1,20-eicos-10-enedioate (Diester A)}

The synthesis of dimethyl 1,20-eicos-10-enedioate was carried out according to procedure already published by our group [24]. 
Into a $100 \mathrm{~mL}$ round-bottom flask equipped with a mineral oil bubbler and a nitrogen inlet, $20 \mathrm{~g}$ (101 mmol) of methyl undecenoate was charged with $85 \mathrm{mg}(0.101 \mathrm{mmol})$ of 2 nd generation Grubbs metathesis catalyst. The contents were vigorously stirred at $45{ }^{\circ} \mathrm{C}$ for $24 \mathrm{~h}$ under dynamic vacuum. After appropriate time, the reaction mixture was cooled to room temperature and $2 \mathrm{~mL}$ of ethylvinyl ether was added to deactivate the Grubbs catalyst. Dynamic vacuum was then applied in order to remove the remaining excess of ethyl vinyl ether. The product was then purified with column chromatography using a mixture of cyclohexane and ethyl acetate as eluent (95/5, v/v). Dimethyl 1,20-eicos-10-enedioate (A) was obtained as a white solid with $98 \%$ purity (determined by GC). ( 28 g, yield: $75 \%$ ).

${ }^{1} \mathrm{H}-\mathrm{NMR}\left(\mathrm{CDCl}_{3}, 25{ }^{\circ} \mathrm{C}, 400 \mathrm{MHz}\right) \mathrm{d}(\mathrm{ppm}): 5.35(\mathrm{~m}, \mathrm{CH}=\mathrm{CH}, 2 \mathrm{H}), 3.65\left(\mathrm{~s}, \mathrm{OCH}_{3}, 3 \mathrm{H}\right), 2.29(\mathrm{t}$, $\left.\mathrm{CH}_{2} \mathrm{COOCH}_{3}, 2 \mathrm{H}\right), 1.99(\mathrm{~m}, 4 \mathrm{H}), 1.60(\mathrm{~m}, 4 \mathrm{H}), 1.27(\mathrm{~m}, 2 \mathrm{OH})$.

\section{Synthesis of Dimethyl 1, 20-eicos-dioate $\left(C_{20} \mathrm{dE}\right)$ (Diester B)}

was obtained by hydrogenation of dimethyl 1,20-eicos-10-enedioate in toluene at $80{ }^{\circ} \mathrm{C}$ with Raney nickel (50\% slurry in water) under hydrogen pressure (50 bar) yielded Dimethyl 1,20dioate $\left(\mathrm{C}_{20} \mathrm{dE}\right)(\mathrm{B})(17.35 \mathrm{~g}$, yield: $62 \%)$.

${ }^{1} \mathrm{H}-\mathrm{NMR}\left(\mathrm{CDCl}_{3}, 25^{\circ} \mathrm{C}, 400 \mathrm{MHz}\right) \mathrm{d}(\mathrm{ppm}): 3.65\left(\mathrm{~s}, \mathrm{OCH}_{3}, 3 \mathrm{H}\right), 2.29\left(\mathrm{t}, \mathrm{CH}_{2} \mathrm{COOCH}_{3}, 2 \mathrm{H}\right), 1.99(\mathrm{~m}$, 4H), $1.60(\mathrm{~m}, 4 \mathrm{H}), 1.27(\mathrm{~m}, 2 \mathrm{H})$. 